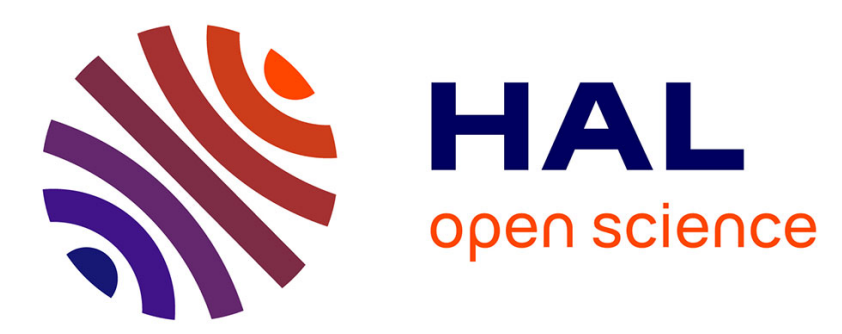

\title{
Effect of phosphorus deficiency on the growth, symbiotic N_2 fixation and proton release by two bean (Phaseolus vulgaris) genotypes
}

Caixian Tang, Philippe Hinsinger, Benoît Jaillard, Zed Rengel, Jean-Jacques Drevon

\section{To cite this version:}

Caixian Tang, Philippe Hinsinger, Benoît Jaillard, Zed Rengel, Jean-Jacques Drevon. Effect of phosphorus deficiency on the growth, symbiotic N_2 fixation and proton release by two bean (Phaseolus vulgaris) genotypes. Agronomie, 2001, 21 (6-7), pp.683-689. 10.1051/agro:2001161 . hal-00886145

\section{HAL Id: hal-00886145 \\ https://hal.science/hal-00886145}

Submitted on 1 Jan 2001

HAL is a multi-disciplinary open access archive for the deposit and dissemination of scientific research documents, whether they are published or not. The documents may come from teaching and research institutions in France or abroad, or from public or private research centers.
L'archive ouverte pluridisciplinaire HAL, est destinée au dépôt et à la diffusion de documents scientifiques de niveau recherche, publiés ou non, émanant des établissements d'enseignement et de recherche français ou étrangers, des laboratoires publics ou privés. 


\title{
Original article
}

\section{Effect of phosphorus deficiency on the growth, symbiotic $\mathrm{N}_{2}$ fixation and proton release by two bean (Phaseolus vulgaris) genotypes}

\author{
Caixian TANG ${ }^{\mathrm{a}, \mathrm{b}}$, Philippe HinsingeR ${ }^{\mathrm{a} *}$, Benoît JAILlARD ${ }^{\mathrm{a}}$, \\ Zed RENGEL ${ }^{\mathrm{b}}$, Jean-Jacques DREVON ${ }^{\mathrm{a}}$ \\ ${ }^{a}$ UMR Sol et Environnement, INRA, place Pierre Viala, 34060 Montpellier Cedex 1, France \\ ${ }^{\mathrm{b}}$ Soil Science and Plant Nutrition, University of Western Australia, 35 Stirling Hwy, Crawley WA 6009, Australia
}

(Received 22 February 2001; revised 19 July 2001; accepted 18 August 2001)

\begin{abstract}
This study compared the growth, nodulation, $\mathrm{N}_{2}$ fixation and proton release by two bean genotypes (Phaseolus vulgaris L., BAT477 and DOR364) in response to P deficiency in nutrient solution. For plants grown at $5 \mu \mathrm{M}$ P for 42 days, shoot and root biomass were 55-62\% and 82-88\%, respectively, of that of plants grown at $25 \mu \mathrm{M} \mathrm{P}$. Phosphorus deficiency decreased nodule biomass and size, with the decrease being smaller in BAT477 than in DOR364. Total nitrogenase activity of plants grown at $5 \mu \mathrm{M}$ P was $50 \%$ of that of plants grown at $25 \mu \mathrm{M}$ P, and reached the maximum earlier in BAT477 than in DOR364. However, nitrogenase activity per unit nodule mass was similar in both genotypes and was unaffected by $\mathrm{P}$ supply. Proton release was generally similar in both genotypes. There were high correlations between proton release and uptake of excess cations, with a slope of 1.44 for BAT477 and 0.85 for DOR364. It is suggested that the two genotypes differ in root exudation.
\end{abstract}

P deficiency / nitrogenase activity / proton release / cation-anion balance

Résumé - Effet de la carence phosphatée sur la croissance, la fixation de $\mathrm{N}_{2}$ et la libération de protons chez deux génotypes de haricot (Phaseolus vulgaris). Cette étude avait pour objet de comparer en termes de croissance, de fixation de $\mathrm{N}_{2}$ et de libération de protons la réponse à la carence en phosphore de deux génotypes de haricot (Phaseolus vulgaris L., BAT477 et DOR364) cultivés sur solution nutritive. Pour des plantes âgées de 42 jours, les croissances aériennes et racinaires des plantes recevant $5 \mu \mathrm{M}$ P étaient respectivement 55-62\% et 82-88\% de celles des plantes recevant $25 \mu \mathrm{M}$ P. La carence P diminuait la masse et la taille des nodosités. Cette décroissance était plus faible chez BAT477 que chez DOR364. L'activité nitrogénase totale des plantes recevant $5 \mu \mathrm{M}$ P était $50 \%$ de celle des plantes recevant $25 \mu \mathrm{M}$ P. L'activité maximale était observée plus tôt avec BAT477 qu'avec DOR364. Néanmoins l'activité nitrogénase par unité de biomasse nodulaire était identique chez les deux génotypes et n'était pas affectée par la carence P. La libération de protons par les racines était corrélée significativement au bilan cations-anions prélevés. La pente de la droite de régression correspondante était de 1,44 avec BAT477 et de 0,85 avec DOR364. Il est conclu que les deux génotypes diffèrent par leurs excrétions racinaires.

déficience en $\mathbf{P}$ / activité de la nitrogénase / équilibre cation-anion / libération de protons

Communicated by Gérard Guyot (Avignon, France)

* Correspondence and reprints

hinsinger@ensam.inra.fr 


\section{INTRODUCTION}

Phosphorus deficiency is one of the most important factors limiting the production of bean (Phaseolus vulgaris L.) in many parts of the world. Phosphorus deficiency appears to affect symbiotic $\mathrm{N}_{2}$ fixation in bean more than in other legume crops [23]. Plants deficient in $P$ had a decreased nodule number [14, 21], and decreased nodule biomass when grown in soil, sand and alkaline solution $[2,14,21]$.

Bean genotypes differ in $\mathrm{N}_{2}$ fixation ability and P-use efficiency under P-deficiency [14, 23, 24]. When subjected to P-deficient conditions in the field, BAT477, a breeding line tolerant to drought, fixes more $\mathrm{N}_{2}$ and yields better than DOR364, a disease-resistant cultivar in Central America (Beebe, personal communication). In addition, BAT477 produced a shallower root system than DOR364, which has been previously related to P-use efficiency [9].

Legume plants reliant on $\mathrm{N}_{2}$ fixation take up more cations than anions and release $\mathrm{H}^{+}$at the root-soil interface $[16,19]$. The increased rhizosphere acidification is a root response to $\mathrm{P}$ deficiency and a strategy of an efficient plant to acquire $\mathrm{P}$ under such conditions [5]. Most of the previous work showing such responses has however been conducted in rather extreme conditions of $\mathrm{P}$ deficiency, comparing P-sufficient plants with plants that received no $\mathrm{P}$ at all $[8,12]$. In addition, responses to low $\mathrm{P}$ supply have been little studied for legumes relying on $\mathrm{N}_{2}$ fixation. It is unknown whether $\mathrm{P}$ deficiency in bean will induce more proton release due to an imbalance of cation-anion uptake by plants relying on $\mathrm{N}_{2}$ and whether bean genotypes differ in proton release and thereby possibly in the capacity to acidify the rhizosphere and enhance $P$ acquisition.

The present study aimed to compare the growth and $\mathrm{N}_{2}$ fixation of BAT477 and DOR364 in response to P deficiency and to study how $P$ deficiency affected cation-anion uptake, and hence proton release in these two bean genotypes differing in tolerance to $\mathrm{P}$ deficiency.

\section{MATERIALS AND METHODS}

The study was conducted in a glasshouse with day/night temperatures of around $30 / 25^{\circ} \mathrm{C}$ and $16 \mathrm{~h}$ photoperiod of natural light supplemented with mercury vapor lamps. The experiment was set up as a complete factorial with two P levels (5 and $25 \mu \mathrm{M}$ ) and two bean genotypes (Phaseolus vulgaris L. BAT477 and DOR364). Treatments were replicated five times and completely randomized.
Uniformly-sized seeds were germinated for $6 \mathrm{~d}$ in vermiculite moistened with deionized water and inoculated with a dense suspension of Rhizobium tropici (CIAT899), containing approximately $10^{8}$ cells $\cdot \mathrm{mL}^{-1}$. One seedling was carefully transplanted to each of $1000 \mathrm{~mL}$ glass bottles. The roots were gently passed through the hole of a rubber stopper on the bottle neck, and cotton wool was fitted at the hypocotyl level. The bottles were wrapped with aluminium foil to maintain darkness in the rooting environment. The bottles contained nutrient solution of the following composition $(\mu \mathrm{M}): \mathrm{K}_{2} \mathrm{SO}_{4}, 700 ; \mathrm{MgSO}_{4}, 500 ; \mathrm{CaCl}_{2}, 800 ; \mathrm{H}_{3} \mathrm{BO}_{3}, 4$; $\mathrm{Na}_{2} \mathrm{MoO}_{4}, 0.1 ; \mathrm{ZnSO}_{4}, 1 ; \mathrm{MnCl}_{2}, 2 ; \mathrm{CoCl}_{2}, 0.2 ; \mathrm{CuCl}_{2}$, 1 ; FeNaEDTA (ferric monosodium salt of ethylenediamine tetraacetic acid), 10; and MES [2-(N-morpholino)ethane-sulfonic acid], 200. Phosphorus was added as $\mathrm{KH}_{2} \mathrm{PO}_{4}$. The rhizobial suspension was added to the solution at a rate of about $10^{8}$ cells $\cdot \mathrm{L}^{-1}$. This solution was kept unchanged for $3 \mathrm{~d}$, then replaced by a similar solution without added rhizobia. The solutions were aerated $[4,22]$ and changed every second day. The solution $\mathrm{pH}$ was adjusted daily to 6.5 with $\mathrm{KOH}$. Solution $\mathrm{pH}$ and amounts of $\mathrm{KOH}$ used were recorded.

Nitrogenase activity of nodules (acetylene reduction activity - ARA) was measured in situ, between 10:00 and 16:00 $\mathrm{h}$ as previously described by Drevon et al. [4], using a steady-flow gas mixture of $69 \mathrm{kPa} \mathrm{N}_{2}, 21 \mathrm{kPa} \mathrm{O}$ and $10 \mathrm{kPa} \mathrm{C}_{2} \mathrm{H}_{2}$, with two replicates each day. To avoid nodule disturbance, the level of the solution was lowered to $70 \%$ of the bottle volume $1 \mathrm{~d}$ before the assay. The $\mathrm{C}_{2} \mathrm{H}_{4}$ concentration in the outflow was determined 2 to 50 min after $\mathrm{C}_{2} \mathrm{H}_{2}$ exposure with a Delsi 30 gas chromatograph (Delsi Instruments, Suresnes, France) equipped with a flame ionization detector. The ARA values were computed as $\mathrm{C}_{2} \mathrm{H}_{4}$ concentration by flow rate, and expressed as $\mu \mathrm{mol} \mathrm{C}_{2} \mathrm{H}_{4} \cdot \mathrm{h}^{-1}$. plant ${ }^{-1}$. The means of 5 replicates were plotted as a function of the median day of the measurement period.

The plants were harvested at 42 DAT (days after transplanting), and shoots, roots and nodules were separated. The plant material was dried and finely ground. A 200-mg subsample of ground material was digested in concentrated $\mathrm{HNO}_{3}$ and then $\mathrm{HNO}_{3}-\mathrm{HClO}_{4}$ according to the AOAC procedure [1]. Phosphate was assayed using the vanado-molybdate method [1]. Sulphur was assayed by inductively coupled plasma emission spectometry (Varian, Australia), while $\mathrm{K}, \mathrm{Na}, \mathrm{Ca}$ and $\mathrm{Mg}$ were assayed by flame atomic absorption spectrometry (Varian AA-600, Australia). For N determination, the 10-30 mg sample of root or shoot material was digested in hot concentrated $\mathrm{H}_{2} \mathrm{SO}_{4}$ [11], with an addition of salicylic acid (10\%). Ammonium in the digest was determined colorimetrically using the phenol hypochlorite 
method [10]. Chloride was measured by high performance ion chromatography (Dionex, USA) after extraction in water for $1 \mathrm{~h}$.

Total amounts of protons released by plants were determined by summing up the amounts of $\mathrm{KOH}$ used for $\mathrm{pH}$ adjustment during plant growth and for titrating the used solution after plant growth to the $\mathrm{pH}$ of the noplant control solution. Concentrations of excess cations in plant were calculated from individual elements as the sum of charge concentrations of $\mathrm{Ca}^{2+}, \mathrm{Mg}^{2+}, \mathrm{K}^{+}$and $\mathrm{Na}^{+}$ minus the sum of $\mathrm{H}_{2} \mathrm{PO}_{4}^{-}, \mathrm{SO}_{4}^{2-}$ and $\mathrm{Cl}^{-}[20]$.

\section{RESULTS}

\subsection{Plant growth and nodulation}

Shoot dry weights of plants grown at $5 \mu \mathrm{M}$ for 42 days was $55-62 \%$ of that of plants grown at $25 \mu \mathrm{M} \mathrm{P}$ (Tab. I). Dry weights of roots were also lower at $5 \mu \mathrm{M} \mathrm{P}$ as compared with $25 \mu \mathrm{M}$ P, but the decrease in root weight by $\mathrm{P}$ deficiency was less than the effect on shoot weight. Consequently, the root/shoot dry weight ratio increased as P supply decreased (Tab. I).

Nodules first appeared at 4 DAT. At 42 DAT the nodule number was not influenced by $\mathrm{P}$ supply or genotype (Tab. I). However, dry weights of nodules decreased with decreasing $\mathrm{P}$ supply. Whereas nodule sizes were similar in both genotypes grown at $25 \mu \mathrm{M} \mathrm{P}$, at $5 \mu \mathrm{M} \mathrm{P}$ the nodule size of BAT477 was twice as much as that of DOR364 (Tab. I).

\subsection{Nodule nitrogenase activity}

Total acetylene reduction activity (ARA) per plant decreased with decreasing P supply (Fig. 1). The plant ARA of BAT477 increased with time and reached a maximum at 31 DAT. Whereas ARA values at 24 and 42 DAT were similar in both genotypes, ARA of BAT477 at 31 DAT was 22 and $65 \%$ higher than that for the Psufficient and P-deficient plants, respectively, of DOR364. By contrast, nodule ARA, i.e. ARA per gram nodule dry weight $\left(\mu \mathrm{mol} \mathrm{C}_{2} \mathrm{H}_{4} \cdot \mathrm{h}^{-1} \cdot \mathrm{g}^{-1}\right.$ nodule) measured at 42 DAT was not significantly affected by $\mathrm{P}$ supply or genotypes (Tab. I).

\subsection{Proton release}

The two genotypes displayed a similar pattern of proton release during the experimental period (Tab. I and Fig. 2). Total proton release was not affected by P supply before 20 DAT for BAT477 and 22 DAT for DOR364.

Table I. Plant growth, nodulation, nitrogenase activity and proton release by two genotypes (BAT477 and DOR364) of Phaseolus vulgaris grown at 5 or $25 \mu \mathrm{M}$ P for 42 days.

\begin{tabular}{|c|c|c|c|c|c|c|c|c|}
\hline \multirow{2}{*}{$\begin{array}{l}\text { Genotypes } \\
\text { P supply }\end{array}$} & \multicolumn{2}{|c|}{ BAT477 } & \multicolumn{2}{|c|}{ DOR364 } & \multirow{2}{*}{$\begin{array}{c}L S D(p=0.05) \\
\text { for any two } \\
\text { means }\end{array}$} & \multicolumn{3}{|c|}{ Significance } \\
\hline & $5 \mu \mathrm{M}$ & $25 \mu \mathrm{M}$ & $5 \mu \mathrm{M}$ & $25 \mu \mathrm{M}$ & & Geno & $P$ & Interaction \\
\hline \multicolumn{9}{|l|}{ Plant growth } \\
\hline Shoot dry weight $\left(\mathrm{g} \cdot \mathrm{plant}^{-1}\right)$ & 1.93 & 3.50 & 1.76 & 2.82 & 0.81 & n.s. & $* * *$ & n.s. \\
\hline Root dry weight $\left(\mathrm{g} \cdot \mathrm{plant}^{-1}\right)$ & 0.80 & 0.98 & 0.79 & 0.90 & 0.20 & n.s. & * & n.s. \\
\hline Root:shoot DW ratio & 0.41 & 0.29 & 0.45 & 0.32 & 0.06 & n.s. & $* * *$ & n.s. \\
\hline \multicolumn{9}{|l|}{ Nodulation } \\
\hline Nodule number (no plant ${ }^{-1}$ ) & 49 & 60 & 69 & 66 & n.s. & & & \\
\hline Nodule dry weight $\left(\mathrm{mg} \cdot\right.$ plant $\left.^{-1}\right)$ & 202 & 341 & 154 & 312 & 68 & n.s. & $* * *$ & n.s. \\
\hline Nodule size $\left(\mathrm{mg} \cdot\right.$ nodule $\left.^{-1}\right)$ & 4.3 & 5.8 & 2.2 & 5.2 & 1.5 & $*$ & $* * *$ & n.s. \\
\hline \multicolumn{9}{|l|}{ Nitrogenase activity } \\
\hline Specific $\left(\mu \mathrm{mol} \mathrm{C}{ }_{2} \mathrm{H}_{4} \cdot \mathrm{h}^{-1} \cdot \mathrm{g}^{-1}\right.$ nodule $)$ & 99 & 86 & 133 & 104 & n.s. & & & \\
\hline \multicolumn{9}{|l|}{ Proton release } \\
\hline Total $\left(\mathrm{mmol} \cdot\right.$ plant $\left.^{-1}\right)$ & 2.52 & 3.17 & 2.39 & 3.01 & 0.45 & n.s. & $* * *$ & n.s. \\
\hline Specific $\left(\mathrm{mol} \cdot \mathrm{kg}^{-1}\right.$ shoot+root $)$ & 1.20 & 0.87 & 1.23 & 0.96 & 0.19 & n.s. & $* * *$ & n.s. \\
\hline Specific $\left(\mathrm{mol} \cdot \mathrm{kg}^{-1}\right.$ root $)$ & 4.56 & 4.43 & 4.34 & 4.35 & n.s. & & & \\
\hline Specific (mol $\cdot \mathrm{kg}^{-1}$ nodule) & 12.9 & 9.5 & 15.9 & 9.9 & 3.4 & n.s. & $* * *$ & n.s. \\
\hline
\end{tabular}

n.s., not significant; *, $p \leq 0.05 ; * *, p \leq 0.01 ; * * *, p \leq 0.001$. 


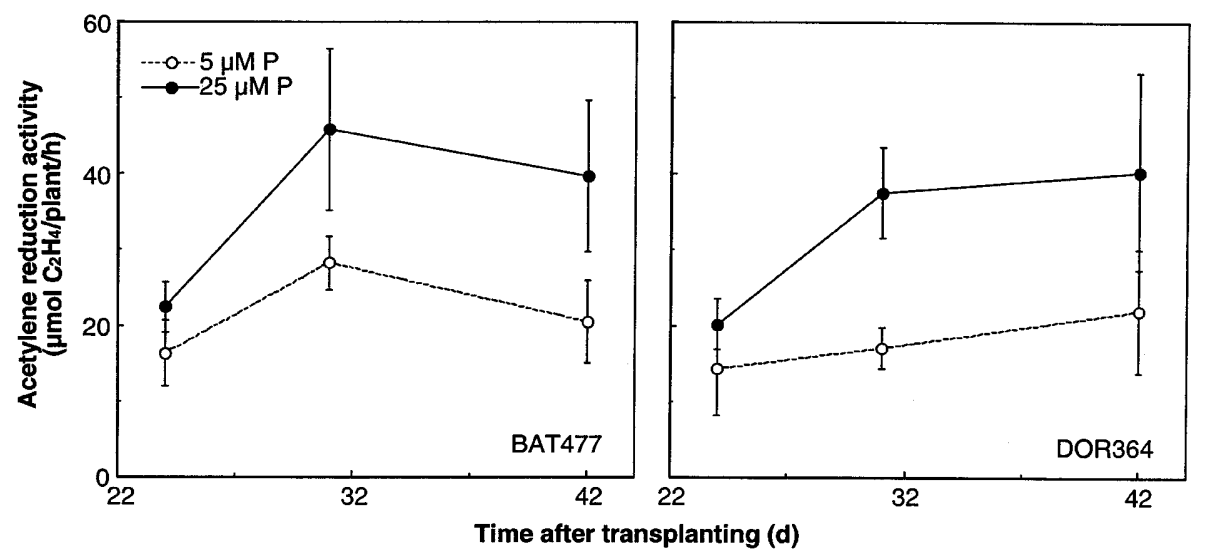

Figure 1. Acetylene reduction activity (ARA) of nodules of BAT477 and DOR364 grown at 5 and $25 \mu \mathrm{M}$ P for 24,31 and 42 days. ARA values represent the average measured between 4 and 50 min after $\mathrm{C}_{2} \mathrm{H}_{2}$ exposure. Vertical bars represent \pm standard errors of means of 5 replicates.

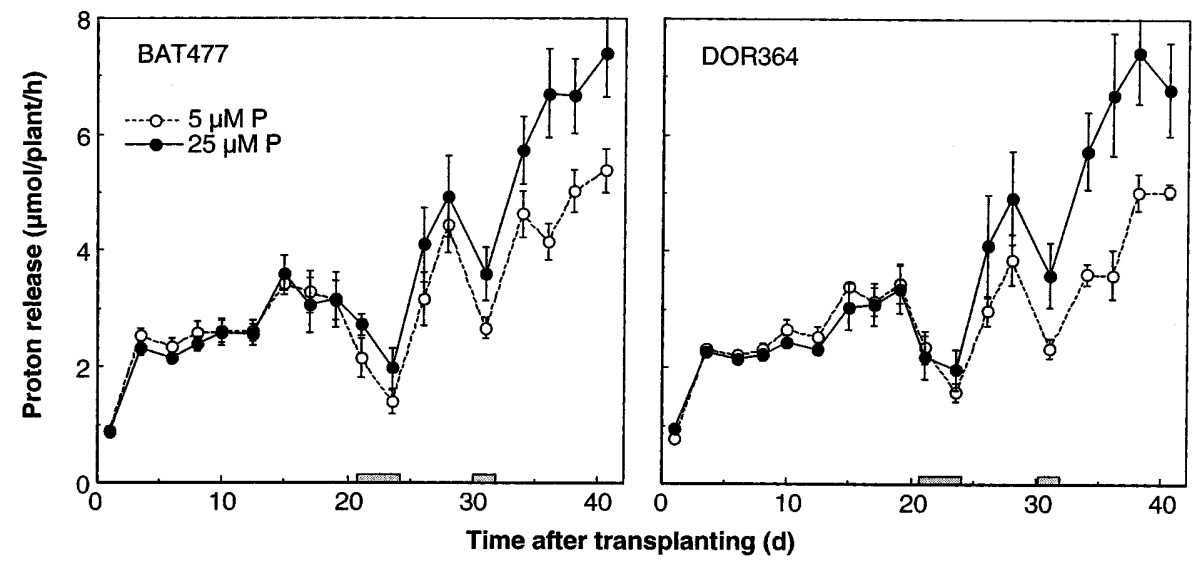

Figure 2. Time course of total proton release of BAT477 and DOR364 grown at 5 and $25 \mu \mathrm{M}$ P for 42 days. Dotted bars on the X axis indicate the time of the acetylene reduction measurements. Vertical bars represent \pm standard errors of means of 5 replicates.

Thereafter, P-deficient plants released less protons than P-sufficient plants (Fig. 2). Total proton release generally increased with time (Fig. 2). The exceptions were that the proton release markedly decreased after each of the ARA measurements, indicating that the ARA measurement was detrimental to root activities.

Total amounts of protons released during the 42-d growth period was $21 \%$ lower in P-deficient plants than in P-sufficient ones (Tab. I). Proton release per unit plant biomass (roots plus shoot) was $28-38 \%$ higher at $5 \mu \mathrm{M} \mathrm{P}$ than at $25 \mu \mathrm{M}$ P. By contrast, proton release per unit root biomass was not affected by P supply (Tab. I). Both total and per unit biomass proton release were not significantly different between the two genotypes (Tab. I).

\subsection{Chemical composition}

Nitrogen concentrations in shoots and roots were not affected by P treatments. The two genotypes had a similar nitrogen concentration in shoots, but BAT477 had higher $\mathrm{N}$ concentration in roots than DOR364 (Tab. II). Total amounts of $\mathrm{N}$ fixed during the experimental period, as determined by the $\mathrm{N}$ budget deduced from plant analysis, were $61-76 \%$ higher at $25 \mu \mathrm{M} \mathrm{P}$ than at 
Table II. Chemical compositions of two genotypes (BAT477 and DOR364) of Phaseolus vulgaris grown at 5 or $25 \mu \mathrm{M}$ P for 42 days.

\begin{tabular}{|c|c|c|c|c|c|c|c|c|}
\hline \multirow{2}{*}{$\begin{array}{l}\text { Genotypes } \\
\text { P supply }\end{array}$} & \multicolumn{2}{|c|}{ BAT477 } & \multicolumn{2}{|c|}{ DOR364 } & \multirow{2}{*}{$\begin{array}{c}L S D(p=0.05) \\
\text { for any two } \\
\text { means }\end{array}$} & \multicolumn{3}{|c|}{ Significance } \\
\hline & $5 \mu \mathrm{M}$ & $25 \mu \mathrm{M}$ & $5 \mu \mathrm{M}$ & $25 \mu \mathrm{M}$ & & Geno & $P$ & Interaction \\
\hline \multicolumn{9}{|l|}{$N$ concentration $\left(\mathrm{mg} \cdot \mathrm{g}^{-1}\right)$} \\
\hline Shoot & 17.0 & 15.5 & 18.3 & 17.6 & n.s. & & & \\
\hline Root & 17.8 & 18.2 & 15.7 & 16.7 & 2.4 & $*$ & n.s. & n.s. \\
\hline \multicolumn{9}{|l|}{$P$ concentration $\left(\mathrm{mg} \cdot \mathrm{g}^{-1}\right)$} \\
\hline Shoot & 1.36 & 2.45 & 1.48 & 3.08 & 0.48 & $*$ & $* * *$ & n.s. \\
\hline Root & 1.43 & 5.20 & 1.38 & 5.21 & 1.07 & n.s. & $* * *$ & n.s. \\
\hline Nodule & 3.16 & 5.38 & 3.37 & 6.33 & 0.79 & $*$ & $* * *$ & n.s. \\
\hline \multicolumn{9}{|l|}{ Total $N$ fixed during days $14-42$} \\
\hline$\left(\mathrm{mg} \cdot\right.$ plant $\left.^{-1}\right)$ & 30.2 & 53.2 & 30.3 & 48.9 & 6.6 & n.s. & $* * *$ & n.s. \\
\hline Molar ratio of $\mathrm{H}^{+}$exuded to $\mathrm{N}$ fixed & 1.19 & 0.87 & 1.12 & 0.91 & 0.23 & n.s. & $* *$ & n.s. \\
\hline \multicolumn{9}{|l|}{ Excess cations $\left(\mathrm{cmol} \cdot \mathrm{kg}^{-1}\right)$} \\
\hline Shoot & 90 & 68 & 109 & 91 & 16 & $* *$ & $* *$ & n.s. \\
\hline Root & 40 & 7 & 45 & 32 & 13 & $* *$ & $* * *$ & $*$ \\
\hline
\end{tabular}

n.s., not significant; *, $p \leq 0.05 ; * *, p \leq 0.01 ; * * *, p \leq 0.001$.

$5 \mu \mathrm{M}$ P, but were not significantly different between the two genotypes (Tab. II). The amounts of protons released per unit $\mathrm{N}$ fixed (molar ratio) were, on average, $23-37 \%$ higher at $5 \mu \mathrm{M} \mathrm{P}$ than at $25 \mu \mathrm{M} \mathrm{P}$ and were not significantly affected by genotype (Tab. II).

Concentrations of $\mathrm{P}$ in plant parts markedly decreased with decreasing P supply (Tab. II). Nodules had higher P concentration than roots at $5 \mu \mathrm{M} \mathrm{P}$, and higher than shoots at both P levels. DOR364 had higher P concentrations in shoots and nodules than BAT477. The amounts of $\mathrm{N}$ fixed per unit $\mathrm{P}$ taken up in both genotypes were 2.4 times higher at $5 \mu \mathrm{M} \mathrm{P}$ than at $25 \mu \mathrm{M} \mathrm{P}$ (data not shown).

Decreasing P supply generally increased concentrations of $\mathrm{K}$ in shoots and $\mathrm{Mg}$ in shoots and roots, and decreased concentrations of $\mathrm{S}$ and $\mathrm{Cl}$ in roots. Compared to BAT477, DOR364 had higher concentrations of $\mathrm{Ca}, \mathrm{K}$ and $\mathrm{Mg}$ in shoots and $\mathrm{K}$ in roots, but had lower concentrations of $\mathrm{Ca}, \mathrm{S}$ and $\mathrm{Cl}$ in roots (data not shown). Decreasing $\mathrm{P}$ supply increased the concentration of excess cations in plants (Tab. II). DOR364 had higher concentrations of excess cations than BAT477 in both shoots and roots (Tab. II), with $\mathrm{Ca}$ and $\mathrm{S}$ contributing most to such differences in shoots and roots, respectively. There were good relationships between the amounts of protons released (Y) and excess cations taken up by the plant $(\mathrm{X})$, with a slope of 1.44 for BAT477 and 0.85 for DOR364 (Fig. 3).

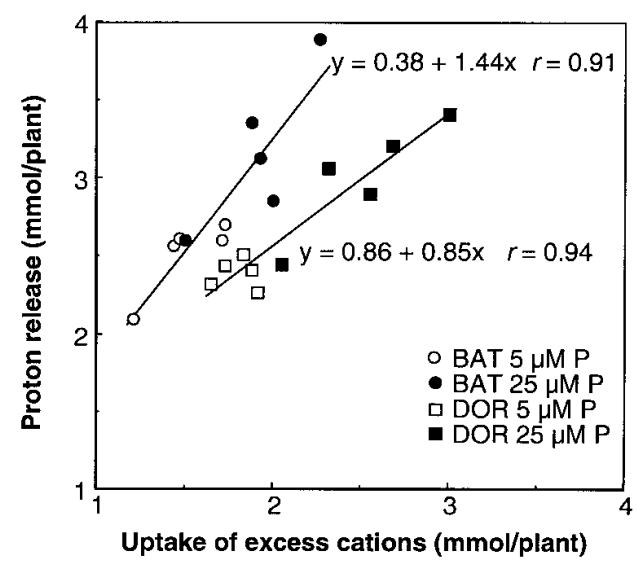

Figure 3. Relationships between total proton release and uptake of excess cations, i.e. excess of positive cationic charges, by BAT477 and DOR364 grown at 5 and $25 \mu \mathrm{M} \mathrm{P}$ during the experimental period. The slopes of the two lines are different at $p<0.05$. 


\section{DISCUSSION}

\subsection{Proton release}

The interesting finding in this study is a genotypic difference in the relationship between proton release and the uptake of excess cations. It was observed that BAT477 released more protons per unit excess cations taken up (a slope of 1.44, Fig. 3) than DOR364 (a slope of 0.85). This indicates that a part of the protons released by BAT477 did not result from the uptake of excess cations. One possible explanation is that BAT477 roots might have released organic anions that were not accounted for in the cation-anion balance. When exuded at large fluxes, organic anions can contribute some significant proportion of cation-anion balance as shown for citrate in white lupins [5, 18].

In the present study, BAT477 and DOR364 displayed the same pattern of proton release in response to P supply. Both genotypes released virtually the same amounts of protons under both adequate and inadequate $\mathrm{P}$ supply when grown in acid solution ( $\mathrm{pH}<6.5)$. Further, the proton release per unit root biomass was not increased under $\mathrm{P}$ deficiency. The results suggest that the rhizosphere acidification may not be an important cause of the genotypic difference in $\mathrm{P}$ acquisition observed in the field. The present results would, however, suggest that BAT477 released more organic anions than DOR364 (cf. Fig. 3). Organic acids in root exudates can mobilize soil inorganic $\mathrm{P}$ through either ligand exchange desorption or complexation of metal cations such as $\mathrm{Fe}$ or $\mathrm{Al}$ and dissolution of P-bearing minerals such as sesquioxides [5]. This process may thus be important in $\mathrm{P}$ mobilization, especially in acidic soils where beans are commonly cultivated. The better efficiency of BAT477 than DOR364 to cope with low $\mathrm{P}$ soils might therefore arise from such difference in their exudation pattern.

Both genotypes showed an increase in the root/shoot ratio under $\mathrm{P}$ deficiency. This is consistent with observations in many plant species efficient in $\mathrm{P}$ utilization $[8$, 15]. This increased root growth relative to shoot growth would thus enhance the total surface area for exploration and acquisition of $\mathrm{P}$ from soil.

\subsection{Nodulation and $N_{2}$ fixation}

Nodule number in both genotypes was not decreased by decreasing P supply in the present study. Supply of $5 \mu \mathrm{M}$ P appeared to be sufficient for optimal nodulation when a large number of nodule bacteria were present. In another solution culture study, nodule number of the same genotypes measured 10 days after rhizobial inoculation was not affected by the absence of $\mathrm{P}$ (unpublished data). Indeed, the growth and survival of rhizobia requires less than $0.5 \mu \mathrm{M} P$ [13]. The results suggest that both P-efficient and P-inefficient bean genotypes require relatively low $\mathrm{P}$ for optimal nodule initiation.

The effect of $\mathrm{P}$ on nodule biomass per plant showed the same pattern as the effect on the shoot growth, indicating that $\mathrm{P}$ deficiency indirectly affects subsequent nodule development by restricting metabolite supply from the host plant. However, DOR364 formed smaller nodules than BAT477 under P deficiency. To compensate for small nodules, P-deficient plants of DOR364 appeared to be able to form more nodules.

Decreasing $\mathrm{P}$ supply decreased total $\mathrm{N}_{2}$ fixation, with BAT477 apparently reaching the maximum $\mathrm{N}_{2}$ fixation earlier than DOR364. Furthermore, P did not appear to have a specific role in nodule functioning in the present study because (i) nodule nitrogenase activity measured at 42 DAT did not decrease with a decrease in external $\mathrm{P}$ concentration from 25 to $5 \mu \mathrm{M}$, and (ii) the amounts of $\mathrm{N}$ fixed per unit nodule mass during 42 days were similar in both P treatments. Similarly, Pereira and Bliss [14] observed that the amount of $\mathrm{N}$ fixed per nodule mass was unaffected by $\mathrm{P}$ deficiency in bean plants grown in a sand-alumina system for 33 days. In other studies where different genotypes were grown in alkaline solutions for various periods, $P$ supply decreased, increased or did not affect the specific nitrogenase activity and/or the amounts of $\mathrm{N}$ fixed per nodule mass [21, 22]. It appears that the role of $\mathrm{P}$ in bean nodule functioning depends on genotypes used, growth conditions and time of measurements.

Nodules appeared to be a strong sink for P since higher $\mathrm{P}$ concentrations were observed in nodules than roots and shoots when P supply was limited. This is in agreement with previous reports in a wide range of legumes $[3,6,7,17,21,23]$. Whatever the $\mathrm{P}$ supply, nodules represented $6-8 \%$ of the total biomass and contained $12-14 \%$ of the total P. By contrast, P deficient shoots decreased their contribution to total biomass but increased their P content, the inverse being observed for roots. Thus, the plants favored $\mathrm{P}$ allocation to the shoots at the expense of the roots.

In conclusion, BAT477 and DOR364 showed similar responses to $\mathrm{P}$ deficiency of $\mathrm{N}_{2}$ fixation and proton release when grown in acid solutions. Therefore, the difference between the two genotypes at the field level may be related to better adaptation of BAT477 to drought, or a difference in their efficiency to absorb and/or use the soil nitrogen. However, BAT477 released more protons per unit excess cations taken up than DOR364. It appears that BAT477 may have released more organic anions than DOR364 to maintain the charge balance. The interactions between $\mathrm{P}$ and exudation of organic anions in 
these two bean genotypes thus deserve further investigation. Direct evidence, and qualitative and quantitative assessments of the organic anions exuded by BAT477 and DOR364 would be needed in the first place.

Acknowledgements: We thank Denis Loisel and Hélène Payré for the maintenance of the solution experiment and ARA measurements, Michaël Clairotte for the plant analyses and the anonymous referees for their constructive comments. The senior author also thanks the OECD (Organisation for Economic Co-operation and Development) for the financial support of his stay at INRA in 1999, within the Programme "Biological Resource Management for Sustainable Agricultural Systems". This research was supported by the EC-INCO project ERBIC18CT960081, namely FYSAME.

\section{REFERENCES}

[1] AOAC (Association of Official Analytical Chemists), Official Methods of Analysis, 12th ed., AOAC Washington DC, USA, 1975.

[2] Araújo A.P., Teixeira M.G., de Almeida D.L., Phosphorus efficiency of wild and cultivated genotypes of common bean (Phaseolus vulgaris L.) under biological nitrogen fixation, Soil Biol. Biochem. 29 (1997) 951-957.

[3] Drevon J.J., Hartwig U.A., Phosphorus deficiency increases the argon-induced decline of nodule nitrogenase activity in soybean and alfalfa, Planta 201 (1997) 463-469.

[4] Drevon J.J., Kalia V.C., Heckmann M.-O., Pédelahore P., In situ open-flow assay of acetylene reduction activity by soybean root-nodules: influence of acetylene and oxygen, Plant Physiol. Biochem. 26 (1988) 73-78.

[5] Hinsinger P., Bioavailability of soil inorganic P in the rhizosphere as affected by root-induced chemical changes $-\mathrm{a}$ review, Plant and Soil (2001) (in press).

[6] Israel D.W., Symbiotic dinitrogen fixation and hostplant growth during development of and recovery from phosphorus deficiency, Physiol. Plant. 88 (1993) 294-300.

[7] Jakobsen I., The role of phosphorus in nitrogen fixation by young pea plants (Pisum sativum), Physiol. Plant. 64 (1985) 190-196.

[8] Le Bot J., Alloush G.A., Kirkby E.A., Sanders F.E., Mineral nutrition of chickpea plants supplied with $\mathrm{NO}_{3}$ or $\mathrm{NH}_{4} \mathrm{~N}$. II. Ionic balance in relation to phosphorus stress, J. Plant Nutr. 13 (1990) 1591-1605.

[9] Liao H., Yan X., Adaptive changes and genotypic variation for root architecture of common bean in response to phosphorus deficiency, Acta Bot. Sin. 42 (2000) 158-163.

[10] Martin F., Winspear J., Macfarlane D., Oaks A., Effect of methionine and sulfomixine on the accumulation of ammonia in $\mathrm{C}_{3}$ and $\mathrm{C}_{4}$ leaves. The relationship between $\mathrm{NH}_{3}$ accu- mulation and photorespiratory activity, Plant Physiol. 71 (1983) 177-181.

[11] McDonald M.S., A simple and improved method for the determination of microgram quantities of nitrogen in plant material, Ann. Bot. 42 (1978) 363-366.

[12] Neumann G., Römheld V., Root excretion of carboxylic acids and protons in phosphorus-deficient plants, Plant and Soil 211 (1999) 121-130.

[13] O'Hara G.W., Boonkerd N., Dilworth M.J., Mineral constraints to nitrogen fixation, Plant and Soil 108 (1988) 93-110.

[14] Pereira P.A.A., Bliss F.A., Selection of common bean (Phaseolus vulgaris L.) for $\mathrm{N}_{2}$ fixation at different levels of available phosphorus under field and environmentally-controlled conditions, Plant and Soil 115 (1989) 75-82.

[15] Raghothama K.G., Phosphate acquisition, Annu. Rev. Plant Physiol. Plant Mol. Biol. 50 (1999) 665-693.

[16] Raven J.A., Smith F.A., Nitrogen assimilation and transport in vascular land plants in relation to intracellular $\mathrm{pH}$ regulation, New Phytol. 76 (1976) 415-431.

[17] Robson A.D., O'Hara G.W., Abbott L.K., Involvement of phosphorus in nitrogen fixation by subterranean clover (Trifolium subterraneum L.), Aust. J. Plant Physiol. 8 (1981) 427-436.

[18] Sas L., Rengel Z., Tang C., Excess cation uptake, and extrusion of proton and organic acid anions by Lupinus albus under phosphorus deficiency, Plant Sci. 160 (2001) 1191-1198.

[19] Tang C., Rengel Z., Role of plant cation/anion uptake ratio in soil acidification, in: Rengel Z. (Ed.), Soil Acidity Handbook, Marcel Dekker Inc., New York, USA, 2001 (in press).

[20] Tang C., Fang R.Y., Raphael C., Factors affecting soil acidification under legumes: II. Effect of phosphorus supply, Aust. J. Agric. Res. 49 (1998) 657-664.

[21] Vadez V., Rodier F., Payre H., Drevon J.J., Nodule permeability to $\mathrm{O}_{2}$ and nitrogenase-linked respiration in bean genotypes varying in the tolerance of $\mathrm{N}_{2}$ fixation to $\mathrm{P}$ deficiency, Plant Physiol. Biochem. 34 (1996) 871-878.

[22] Vadez V., Beck D.P., Lasso J.H., Drevon J.J., Utilization of the acetylene reduction assay to screen for tolerance of symbiotic $\mathrm{N}_{2}$ fixation to limiting $\mathrm{P}$ nutrition in common bean, Physiol. Plant. 99 (1997) 227-232.

[23] Vadez V., Lasso J.H., Beck D.P., Drevon J.J., Variability of $\mathrm{N}_{2}$-fixation in common bean (Phaseolus vulgaris L.) under $\mathrm{P}$ deficiency is related to $\mathrm{P}$ use efficiency, Euphytica 106 (1999) 231-242.

[24] Yan X., Lynch J.P., Beebe S.E., Genetic variation for phosphorus efficiency of common bean in contrasting soil types: II. Yield response, Crop Sci. 35 (1995) 1094-1099. 